\title{
International Committee on Systematics of Prokaryotes
}

\section{Subcommittee on the taxonomy of Agrobacterium and Rhizobium}

\author{
Minutes of the meeting, 4 July 2001, Hamilton, Canada
}

Minute 1. Call to order. An open meeting was called to order by M. E. Martínez-Romero at 19:00 on 4 July 2001.

Minute 2. Record of attendance. The members present were P. van Berkum, B. Eardly, M. Gillis, K. Lindström and M. E. Martínez-Romero. Apologies were received from W. X. Chen, B. D. W. Jarvis, G. Laguerre, P. de Lajudie and J. P. W. Young. N. Amarger, C. Boivin-Masson, D. Prevost, P. Vinuesa and A. Willems were present as invited guests.

Minute 3. The role of the committee. The role of the committee was seen to have changed. The review of published proposed new species is no longer seen as the main task, instead, emphasis is put on presenting guidelines for the description of new taxa and providing a forum for discussions within the scientific community working with the organisms. New guidelines for species description are needed, but it was decided to wait until a new prokaryotic species concept emerged integrating new data reflecting progress in genomics.

Minute 4. The home page. A website on rhizobial taxonomy is being prepared by the secretary, with links to useful sites and with room for discussions (http:// honeybee.helsinki.fi/users/lindstro/rhizobium/index.htm).

Minute 5. What should we call nodulating bacteria? Reports during the 13th International Congress on Nitrogen Fixation about nodulation of legumes by members of the $\beta$ subclass of Proteobacteria [genus Burkholderia, Moulin et al., Nature 411 (2001), 948-950] and Methylobacterium sp. [Sy et al., J Bacteriol $\mathbf{1 8 3}$ (2000), 214-220] raised the question whether these should be called 'rhizobia'. Should 'rhizobia' be reserved for bacteria with the word 'rhizobium' in its Latin name or should 'rhizobia' refer to nodulation ability (the presence of nod genes)? However, no recommendation was made. It is questionable whether the nodulating bacteria in the $\beta$-subclass come under the mandate of this committee.

Minute 6. New species. The following new species have been described since the last meeting: Agrobacterium larrymoore $i$ [Bouzar \& Jones, Int J Syst Evol Microbiol 51 (2001), 1023-1026], which infects Ficus benjamina; Mesorhizobium chacoense [Velázquez et al., Int J Syst Evol Microbiol 51 (2001), 1011-1021], which nodulates several legumes in the arid regions of China; Sinorhizobium arboris and S. kostiense
[Nick et al., Int J Syst Bacteriol 49 (1999), 1359-1368], which nodulate Acacia and Prosopis species.

Minute 7. The proposition to merge Agrobacterium with Rhizobium. Young et al. [Int J Syst Evol Microbiol 51 (2001), 89-103] have proposed that the genus Agrobacterium should be fused with the genus Rhizobium. Scientists should be aware of this proposition. This nomenclature has been adopted in the Jean Euzéby's List of Bacterial Names with Standing in Nomenclature (http:/ / www.bacterio.cict.fr) because this list is regularly updated with all new names proposed in IJSEM. The latest proposition of any new name does not automatically mean that this name has preference. It is up to the scientific community to decide which of the available synonymous names (both validated names) for the same taxon they prefer to use (on the basis of available results). Consequently, the committee suggest that it is up to individual experts and/or authors to choose (and to give arguments) which name they want to use.

Minute 8. Sinorhizobium-Ensifer. The genus Ensifer (with a single species) was proposed in 1982 on the basis of phenotypic data but without $16 \mathrm{~S}$ rRNA results about its phylogenetic position. Later (1988) the genus Sinorhizobium was proposed. Phylogenetic evidence for this proposal was presented in 1994 and several species were described. Recently, the 16S rDNA sequence of Ensifer adhaerans became available showing that it is phylogenetically part of the Sinorhizobium lineage. Both genera clearly belong to a single taxon. However, according to the Bacteriological Code (Rule 42), when two taxa of equal rank have to be united the oldest legitimate name (Ensifer) has priority. There are good reasons for retaining the name Sinorhizobium over Ensifer; hence, a case to this effect needs to be prepared for consideration by the Judicial Commission.

Minute 9. Current membership of committee. M. E. Martínez-Romero (Chairperson; Mexico), K. Lindström (Secretary; Finland), P. van Berkum (USA), R. A. Bradley (Costa Rica), B. Eardly (USA), W. X. Chen (China), M. Gillis (Belgium), P. H. Graham (USA), B. D. W. Jarvis (New Zealand), G. Laguerre (France), P. de Lajudie (France) and J. P. W. Young (UK). B. Dreyfus (France) has been replaced by $\mathrm{P}$. de Lajudie and J. E. Cooper (UK) has resigned.

Minute 10. Adjournment. The meeting was adjourned at $20: 30$.

K. Lindström, Secretary M. E. Martínez-Romero, Chairperson 